\title{
THE ORGANIZATION OF EVENTS: A POSSIBILITY OF TOURISM REVIVAL AFTER COVID? THE CASE OF SIBIU
}

\author{
Ana-Maria Nica ${ }^{1 *}$, Adina Irina Lăceanu ${ }^{2}$ \\ ${ }^{1}$ Bucharest University of Economic Studies, Romania, ana.nica@com.ase.ro \\ ${ }^{2}$ Bucharest University of Economic Studies, Romania, laceanuadina16@stud.ase.ro
}

\begin{abstract}
The MICE (Meetings, Incentives, Congresses, Exhibitions) market has recently experienced a rapid growth, as actors at both macroeconomic and microeconomic levels recognized the great potential of this kind of tourism income generator. The events have also become elements that helped shape a tourism destination image or brand, through organized systems such as the portfolio model. However, the Covid pandemic, with its subsequent limitations and economic crisis, has severely impacted the events industry. No events, at any scale, were allowed to be organized, thus resulting in losses of billions of euros worldwide. With the economies slowly reopening, due to the partial lifting of Covid-related limitations, there seems to be room for the revival of tourism destinations.

The analysis of previous studies has revealed a scientific gap, related to the possibility of reviving an urban destination through a large scale event. Therefore, the aim of the present scientific paper is to fill this gap, by looking into the perception of potential tourism demand on this subject. It also investigated the specifics of such an event, with a focus on the Romanian city of Sibiu. To this end a survey was conducted in the beginning of the year 2021, and its main results are presented in this article.
\end{abstract}

Keywords:

Tourism events, Covid pandemic, destination image, festivals

JEL Classification: L82, L83

DOI: $10.24818 / \mathrm{CTS} / 3 / 2021 / 1.04$

\section{Introduction}

Events, whether tourism or otherwise, have become in recent decades of utter importance to the local economies (Getz, 2008). The term is often utilized in the literature in different contexts, defining either a manifestation of social, sporting, cultural nature such as congresses, music or food festivals, reunions or a special, unique happening that gives way to emotions or a remarkable, life-shaping experience (Stanciulescu, 2010; Lugosi et al., 2020; Gholiopur et al., 2020).

Nonetheless, no matter their nature, events tend to encompass a large number of benefits, including generating further tourism demand, large amounts of revenue, media coverage, but also helping shape the destination brand, by animating the locations and also developing their infrastructure. Other benefits are the capability to attract demand over off-season periods of time but also the involvement of all tourism related services in the process. (Lugosi et al., 2020).

According to Getz (2015), the evolution and pre-Covid perspectives of tourism events were considered skyrocketing, both in the theoretical parts and mainly in the marketing ideas implemented in the tourism industry.

The Covid pandemic brought along numerous limitations that led to massive closure of economies and cancellations of pre-scheduled events all over the continents. The pandemic restrictions, even after they are partially lifted, led to issues such as pandemic travel fear, that subsequently leads to the reluctance to travel altogether, or social distancing that further gives way to concerns regarding being around other people in the same space and at the same time (Drury et al., 2021).

The present scientific paper presents, in the Literature Review section, insights on MICE (Meetings, Incentives, Congresses, Exhibitions), with special focus on tourism oriented events, the impact of the Covid pandemic on this sector and the hypotheses of its recovery in the upcoming period. The research

\footnotetext{
* Contact author
} 
is aiming to investigate the perception and expectations of potential tourists regarding the revival of tourism events in the Transylvania region of Sibiu. This analysis is performed through the use of a quantitative method and is detailed in the Methodology section of this article. The Main findings section presents an overall on the results of the survey, providing insights on what tourists require in order to choose to participate in an event during the Covid pandemic period.

\section{Literature review}

\subsection{Destination image and the event portofolio model}

Urban tourism is composed by many attractions for visitors such as: beauty of public squares, restaurants and bars, beauty of boulevards, street cleanliness, and friendliness of local people, restful atmosphere and a wide variety of shops ( $\mathrm{Li}$ et al., 2018). Nowadays, tourists decide to go to visit urban places especially for other reasons besides than the heritage resources. The focus is more on entertainment facilities, even if they are combined with activities linked to heritage tourism, cities being recognized by the mix between socio-cultural and economic activities. The urban tourism has three main types of impact in the society through which are mentioned the economic impact, social, and cultural combined with environmental (Su et al., 2018).

Tourism image of a city is drawn by geographical, natural and historical particularities, but in relation with local traditions and local food which helps the persons to distinguish that specific site. Destination branding is the best way for attracting the travelers' attention, people being attracted by the unique and original assets of a place. The place identity varies from one city to another, so people need to search the uniqueness of every place in order to have the best experience (Truonga et al, 2018).

A touristic organization build a promotional campaign focusing on the main object of the campaign. The most well-known campaigns in marketing tourism are those where they promote the touristic products or services, focusing more on informing the consumers about the presence of some touristic products or services (Agusti, 2018).

The tourism image of a destination is also influenced by some myths and events happening inside its borders. Recent literature presents how touristic destinations are building their strategies for attracting more visitors and the perfect way for doing that is to organize new events, because it has a lot of benefits like increasing the spending, expanding tourism geographically and also controlling the seasonality (Mariani and Giorgio, 2017).

The events which happen in a region contribute in a positive way to the improvement of the touristic image of that destination and also boosting the revenues. Like is previously mentioned, one of the most important benefits is the economical one, but also mega-events can conduct to the creation of new work places and modernization of infrastructure (Paraman and Ali, 2021). This system is also known as the portofolio model, which implies the existence of a four-tier pyramid that helps shape a certain area as a tourism event destination. In order for the destination to be branded as such, it should strategize the organization of four types of events: local, regional, periodic hallmark events and occasional megaevents (Mogollon and Duarte, 2018).

\subsection{MICE - past development and future perspectives}

The MICE market is segmented by various characteristics, but one of them is by important variables such as geographic segmentation which mainly refers to the place of residence of the possible participants at the event, psychographic which divides the potential market in terms of lifestyle, attitudes and values, demographic segmentation which takes into characteristics such as the age, gender, religion, occupation, social status, level of education and culture, income and behavioral ones which outline the customers' attitudes and expectations, the customer loyalty to certain events, engagement level and frequency participation.

This events market segmentation bring benefits mainly for the marketing plan of an event organization, being one of the stages in the strategy planning process. It is obvious that event organizers who will have a clear targeted segment are prone to obtain a competitive advantage and also it is noticed they target also a secondary. According to the International Congress and Convention Association - ICCA (2020), a global community affiliated to World Tourism Organization (UNWTO), the cities that ranked 
first in terms of number of organized events were: Paris, which occupied the top row for two consecutive years, Lisbon and Berlin. The same report indicates the USA as the top worldwide event organizer, followed by Germany, France and Spain.

As shown in Graph 1, according to a study (Paraman and Ali, 2021), the MICE industry was expected to grow at a steady pace by 2025 , from around 800 billion euros worldwide to a forecasted 1,440 billion by the year 2025. However, the overall year situation of 2020 has shown, according to GlobalData (2020), a fall by $35 \%$ in the revenue obtained from the organization of events.

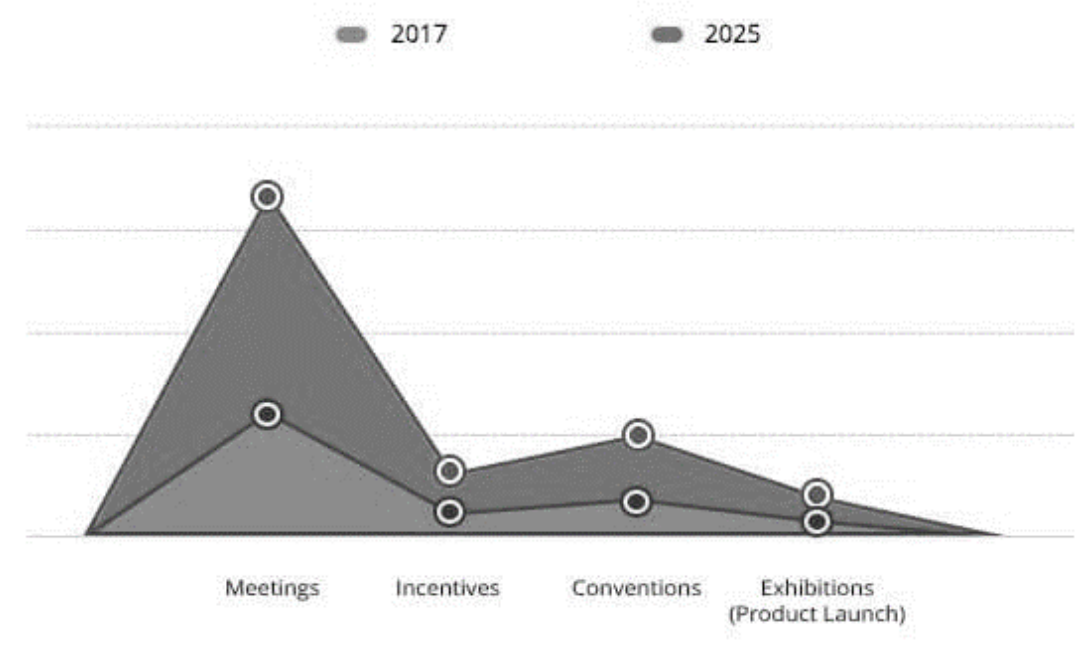

Fig. no. 1: Global MICE industry perspectives by type of events Source: Paraman and Ali, 2021

Taking into consideration the 2020 was an atypical year, the map of the world events suffered changes, so $44 \%$ of them were postponed, $30 \%$ were moved to virtual, unfortunately $14 \%$ were cancelled, a small percentage of $9 \%$ remained unaffected, as shown in graph 2 (ICCA, 2020).

Tourism is one of the sectors which was most affected by the COVID-19 pandemic, because of the travel restrictions that the authorities have imposed at worldwide level. The Covid pandemic has put both the European tourism industry and the world tourism industry under fantastic pressure (GlobalData, 2020). As it has conducted to the annulment of many domestic and international travels, because EU member states introduced isolation strategies, closing borders and suspending flights, generating a significant cut in revenues and also liquidity problems for all tour operators. Millions of persons who have booked accommodation, had to cancel or to change the destination in order to protect public health (European Parliament, 2020).

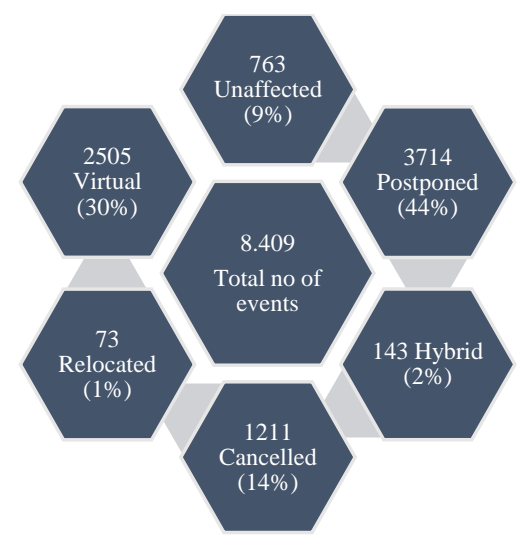

Fig. no. 2: The number of events by status in 2020 Source: Adapted based on ICCA, 2020 
The solutions given by the European Commission for the customers who bought an event ticket and the event was not happening anymore were to reach the event organizer for obtaining a reasonable solution and maybe to accept alternatives if the full refund is not possible in that moment. It is normal to predict that people will want to visit new destinations and to travel more and more when the pandemic situation will be under control.

According to a global meetings and events agency, BCD Meetings\&Events LLC, in 2021 the events and meetings industry will experiment changes due to global pandemic situation and they will take also the hybrid and virtual form, live events being very narrow, especially in the first half of the year. The MICE industry built up an online environment with online meetings, which will bring new challenges for events and meetings industry, conference centers and hotels being empty and virtual studios being overbooked.

\section{Methodology}

The research was conducted using a quantitative method. A survey, based on a 15 questions questionnaire, was developed and applied in the months of March through May of 2021.

The main scope of the survey was to determine the perception of potential demand representatives regarding the possibilities of tourism revival of the city of Sibiu through tourism events, in the context of the Covid pandemic. A secondary objective of the research aimed at determining the exact organization conditions of the event required by the potential demand in order for them to be willing to participate.

The questionnaire was administered online, using a specialized platform. The total number of respondents was 159 and no significant obstacles were observed during the administration of the form.

There are several reasons behind choosing Sibiu, the capital city of Sibiu county as a case study for the conducted research. It is an important cultural and economic center in southern Transylvania, with a population of 147,245 inhabitants according to the 2011 census (Consiliul Judetean Sibiu, 2021). Since 2007, when Sibiu represented the European capital of culture together with Luxembourg, no significant effort towards the revival of the city image was performed. Sibiu is the backdrop of smaller scale, local events, based on folklore, local gastronomy and traditions, therefore the potential need for diversification was aroused. Another reason for conducting this research was the Covid-19 pandemic, as the tourist behavior in the second half of 2020 and first half of 2021 has shown a preference for domestic tourism. However, tourists have been reluctant to travel to potentially crowded tourism destinations such as cities, and even more cautious at the time to be part of a bigger scale events. Therefore, cities have suffered high-scale losses of tourism revenue (Arbulu, 2021).

\section{Results}

The total number of valid answers was 159 responses, from which 110 people belong to 20-30 group age, 31 persons belong to 31-40 age group, 15 persons were from less than 20 years category and 3 persons were over 40 years.

Concerning the gender of respondents, the questionnaire was completed $65 \%$ female and $35 \%$ male respondents. The next demographic question was related to marital status and we noticed that approximately half of respondents $(43.5 \%)$ are in a relationship, $30.4 \%$ of them fall into "alone" category, $22.8 \%$ are married and 3 persons are divorced. Another useful finding is that 132 persons already visited the city. Another question was related to the financial profile of the respondents. When asked about their monthly income, $41.3 \%$ indicated the category 500-1000 euro and 38\% chose the category of more than 1000 euro.

Another question which was included in the questionnaire was introduced to obtain a general brand image of Sibiu. This question was introduced in the questionnaire based on the model of the projective techniques of research, and appeals to potential respondents to specify the first word that comes to mind when thinking about Sibiu. We can mention that from the answers received at this question, it is clear that Sibiu is perceived different by the respondents. The most frequent answers to this were related to history, cultural attractions, quiet and tranquility, fun, special architecture and Transylvanian traditions, 
but also, they associated Sibiu with some events such as Christmas Market, Movie Festivals and Media Music Awards which in this case can represent focal points of the destination.

Another question, most relevant for the scope of the research, asked the respondents to choose what type of event they would want to participate in. The results have shown that the potential demand is most interested in participating was Music Festival, with $42.4 \%$ of the total responses, the 2nd favorite option was the Film Festival with a percentage of $25 \%$, the next voted option was Concert with $16.3 \%$.

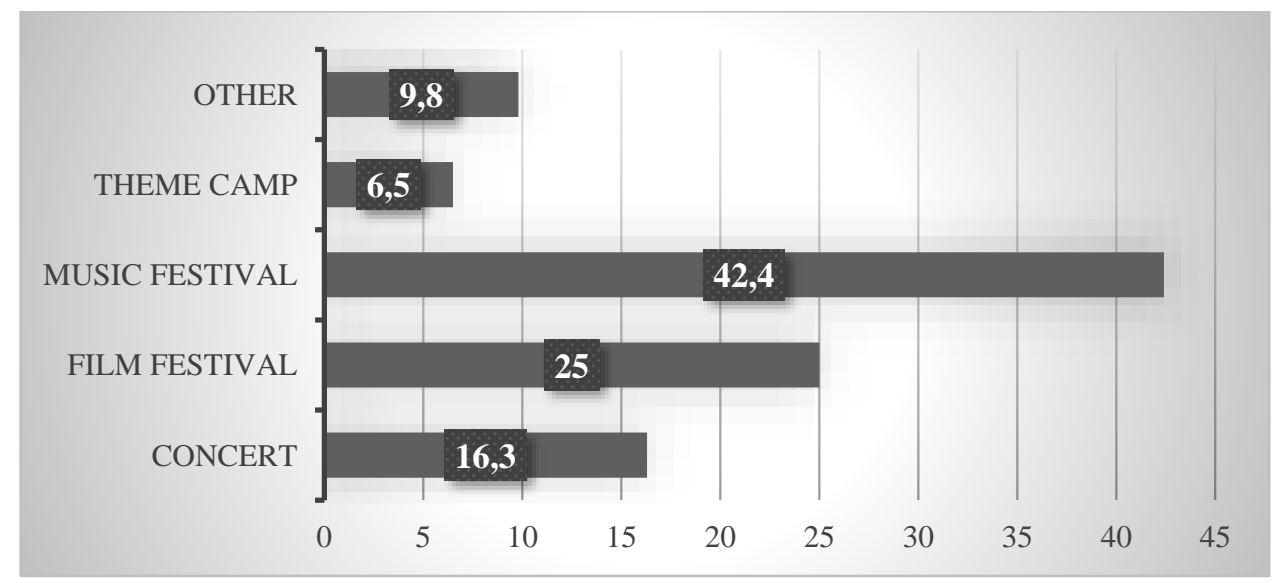

Fig. no. 3: Preferred types of events in the Covid pandemic context (\%) Source: Own research

The questionnaire includes also an optional question for those who opted for the Music Festival at the previous question and it was referring to the artists they would like to see perform at the festival. To this question there were 44 answers, which mentioned Romanian artists like: Cargo, Parazitii, Carla's Dreams, Delia, Andra, Lino Golden, Inna,The Motans and famous international DJs as Armin Van Buren, Martin Garrix, Boris Brejcha, Solomun, Kashmr, Afro Jack and also worldwide known names such as Jason Derulo, Rihanna, Eminem, The Weekend, G-eazy, Dua Lipa.

Another important question is related to event duration and as it can be observed below in graph 4 below, the first place was taken by the answers with 2-3 days with a percentage of $56.5 \%$, followed by 1-2 days with $34.8 \%$ and on the last place is 3-4 days.

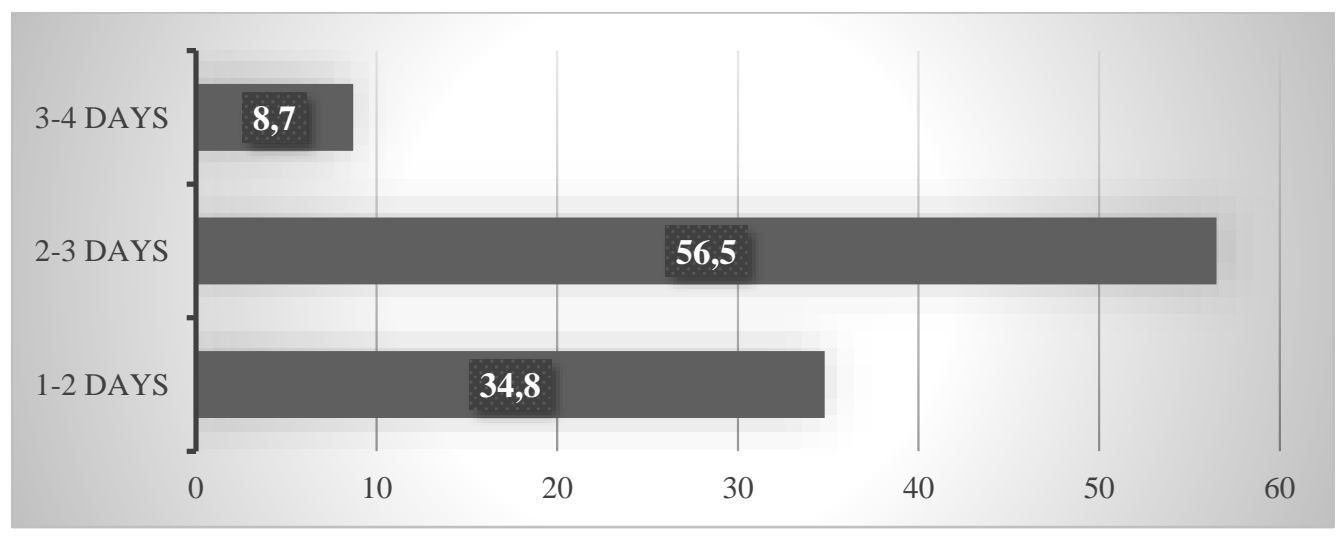

Fig. no. 4: The preferred duration of the event, in the Covid pandemic context (\%) Source: Own research

Also, in order to have a more complete overview of the potential demand, we need to know how much they are willing to spend for joining an event in Sibiu. Correlated with the age and income, the category 
that indicated a price of 50 to 99 euros seems adequate. This answer is, however, followed closely by the next category (100 to 149 euros), with $39 \%$ of the responses.

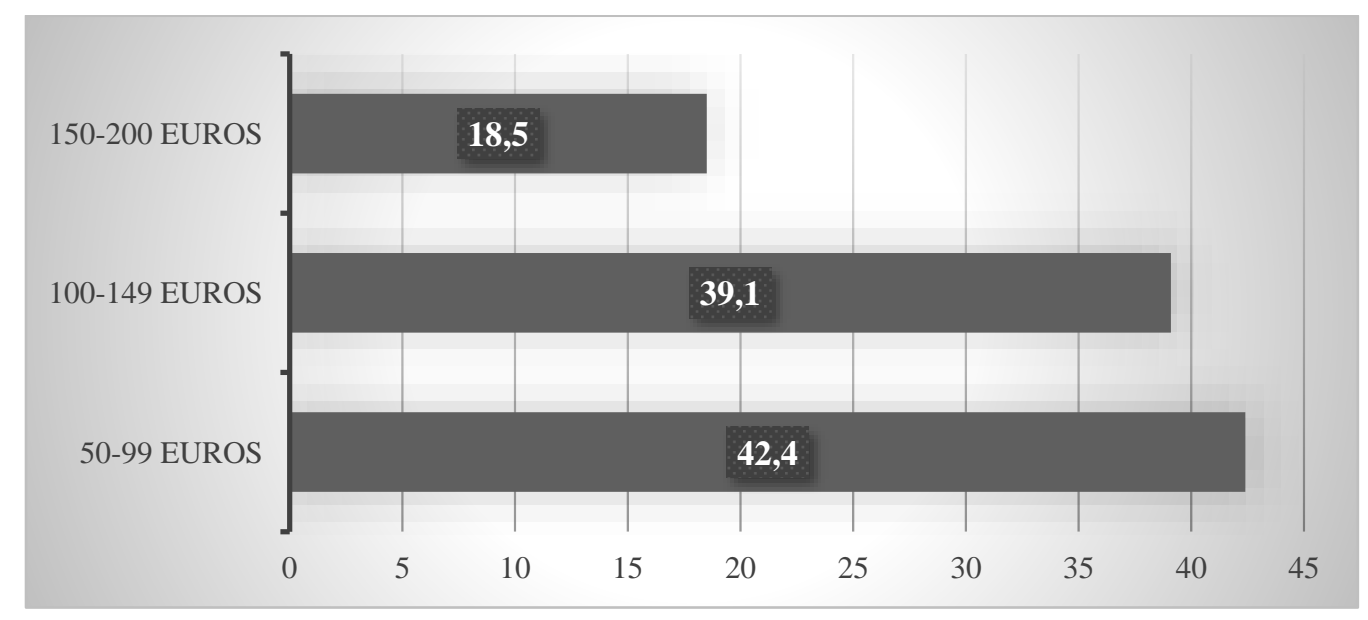

Fig. no. 5: The amount willing to pay for participating in the event, in the Covid pandemic context (\%)

Source: Own research

We have included also in the questionnaire an optional question with open answer regarding the event theme and the most interesting answers received by us were: Covid-19, fantasy, romantic, white party, historic, futuristic theme and vintage. (See Fig 7 from Annexes)

Another question was focused on the favorite music style and it is strongly linked to the previous one about the people's desires regarding the artists they would want to see at the event. As it can be observed below in graph 6 , the music style which is on the top preferences with almost $60 \%$ is commercial music.

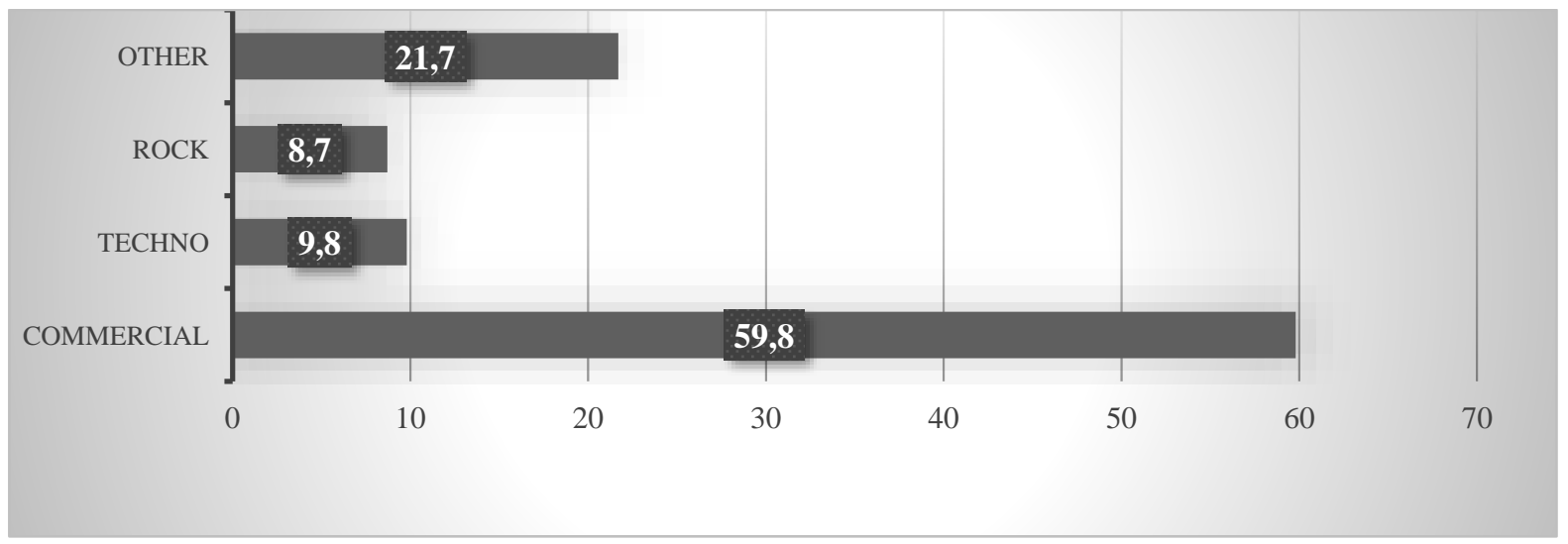

Fig. no. 6: The preferred music style at the event, in the Covid pandemic context (\%)

Source: Own research

It is also important to know which are the factors that influence the participation in an event and we found that the main reason is the music and dance, with $30.4 \%$ of the answers, the second factor is the atmosphere and the crowd, followed closely by avoiding the daily routine.

The location of the event is also a very important aspect and respondents had to choose from 3 options, in the context of the Covid pandemic: Piata Mare Sibiu, Parcul Sub Arini and Stadionul Municipal. A vast majority ( $81.5 \%$ of the respondents) indicated the first option as the preferred location for the development of the event. 
The respondents were also asked about the number of participants/day that they consider appropriate, given the actual pandemic context. The limitations imposed by the Government regulations require the participants to present a vaccination certificate or a rapid test for Covid-19. 35.9\% of respondents had chosen 500-1000 participants/day, 30.4\% voted over 2000 persons per day, almost $22 \%$ opted for less than 500 people/day and $12 \%$ of respondents voted 1000-2000 persons/day.

\section{Conclusions}

Over the recent decades, tourism events have experienced a rapid growth in importance, under economic, social and cultural factors. The behavior of the demand representatives has also undergone changes, with ever time more people willing and eager to take part in an organized event of different specifics, categories. Worldwide, the MICE industry appealed to more and more destinations, some of them being shaped around the requirements necessary in order to accommodate specific segment of tourists participating in events.

The Covid pandemic brought along prolonged periods of general lockdown, limitation of sanitary but also social dimensions. Lately the Governments have started to partially lift the imposed regulations related to the Covid pandemic, however there is still reluctance on the side of the tourism demand towards engaging in all the possible tourism activities, like before the year 2020. Domestic tourism has registered an increased growth; however, the big cities and events have been less appealing to tourists. This scientific article was aimed at investigating the perception of potential tourism demand for tourism events, in the present Covid pandemic. The research looked into elements of description of the segment of potential tourists, in terms of socio-demographic factors, but, more important, of their consumer behavior as tourists participating in an event organized during the pandemic.

The main results indicate that there is sufficient demand for larger scale tourism events during the ongoing pandemic period. The respondents have shown interest in participating in a large scale music festival, describing also elements related to the preferred duration or the amount of money they would be willing to spend for this kind of event. Nonetheless, in order to ensure the safety feeling, there are sine qua non requirements that need to be met, related to the availability of hand sanitizers, use of masks or the maximum number of allowed participants.

A limitation of the present study is the focus placed on only one city in Romania, i.e. Sibiu. Another limitation of the research refers to the respondents, as their number and age diversity might have acted as a bias factor in the context of the results interpretation.

A direction of future research includes a larger scale study regarding the consumer behavior of tourists that are willing to participate in tourism events. Another proposal for future investigation refers to a greater diversification of the age groups, in order to obtain a more detailed image of the phenomenon in Romania.

\section{References}

Agustí, P., 2018. Characterizing the location of tourist images in cities. Differences in user-generated images (Instagram), official tourist brochures and travel guides, Annals of Tourism Research, 73, pp. 103-115.

Arbulú, I., Razumova, M., Rey-Maquieira, J. and Sastre, F., 2021. Can domestic tourism relieve the COVID-19 tourist industry crisis? The case of Spain. Journal of Destination Marketing \& Management, 20 (1).

BCD Meetings\&Events, 2021. BCD Meetings \& Events report: What's trending this year. Available at: https://www.bcdtravel.com/move-global/bcd-meetings-events-report-whats-trending-this-year/, [accessed 20.05.2021].

Consiliul Judetean Sibiu, 2021. Available at: https://www.cjsibiu.ro/culturale/, [accessed 19.07.2021].

Drury, J., Rogers, M.B., Marteau, T.M., Yardley, L., Reicher, S. and Stott, C., 2021. Re-opening live events and large venues after Covid-19 'lockdown': Behavioural risks and their mitigations. Safety Science, 139.

European Commission, 2020. The EU against COVID. Available at: https://eeas.europa.eu/ headquarters/headquarters-homepage/85749/node/85749_ro, [accessed 20.05.2021].

European Parliament, 2020. Tourism and travel plans: Committee welcomes Commission's package to overcome COVID-19 crisis. Available at: https://www.europarl.europa.eu/news/en/press-room/20200512IPR78908/ tourism-and-travel-committee-welcomes-commission-s-package-to-overcome-covid-19, [accessed 15.11.2020].

Getz, D., and Page, S. J., 2008. Progress and prospects for event tourism research. Tourism Management, pp. 593-631. 
Gholipour, H., Arjomandi, A., Marsiglio, S. and Foroughi, B., 2020. Is outstanding performance in sport events a driver of tourism? Journal of Destination Marketing \& Management, 18(1), pp. 343-340.

GlobalData, 2020. MICE industry might never recover from Covid-19. Available at: https://www.globaldata. com/mice-tourism-may-never-fully-recover-from-covid-19-as-international-business-arrivals-set-to-fallby-35-3-in-2020/, [accessed 20.02.2021].

ICCA, 2020. Annual Statistics Study. Available at: https://www.iccaworld.org/cnt/Research/ICCA\%20Statistics \%20Study\%202020_270521_Final.pdf, [accessed 25.11.2020].

Li, J., Deng, J. and Pierskalla, C., 2018. Impact of attendees' motivation and past experience on their attitudes toward the National Cherry Blossom Festival in Washington, D.C. Urban Forestry \& Urban Greening, 36(1), pp. 57-67.

Lugosi, P., Robinson, R.N.S., Walters, G. and Donaghy, S., 2020. Managing experience co-creation practices: Direct and indirect inducement in pop-up food tourism events. Tourism Management Perspectives, 35, pp. 21-25.

Mariani, M., and Giorgio, L., 2017. The „Pink Night” festival revisited: Meta-events and the role of destination partnerships in staging event tourism. Annals of Tourism Research, 62, pp. 89-109.

Mogollon, J. and Duarte, P., 2018. The contribution of cultural events to the formation of the cognitive and affective images of a tourist destination. Journal of Destination Marketing \&Management, 9, pp. 170-178.

Paraman, P. and Ali, L., 2021, Mesoscopic laddering in consumer behaviour: Analyzing the modalities of consumption on a micro-individual scale in the Meeting, Incentive, Conference, Exhibitions (MICE) sector. Spatial Statistics, 21(1).

Stanciulescu, G., 2010.Managementul Operatiunilor in Turismul de Evenimente. Bucuresti, Romania: ASE Publishing House.

Su, R., Whalley, B., 2018. Cultural political economy and urban heritage tourism. Annals of Tourism Research, 68, pp. 30-40.

Truonga, T. L., Lengleta, F. and Mothea, C., 2018. Destination distinctiveness: Concept, measurement, and impact on tourist satisfaction. Journal of Destination Marketing \& Management, 8, pp. 214-231. 